\title{
J(ब)
}

\begin{tabular}{||l||c|c||}
\hline Received 15.12.2021 & & JOTS \\
$6 / 1$ \\
\hline \hline Accepted 25.12.2021 & Review & $2022: 221-242$ \\
\hline \hline Published 01.01.2022 & & \\
\hline
\end{tabular}

\section{Alyılmaz, C. Bilge Tonyukuk Yazıtları, Ankara: Türk Dil Kurumu Yayınları, 2021, ss. XII+ 518. ISBN: 978-975-17- 4884-3}

\author{
Erdem UçAR* \\ Friedrich-Schiller-Universität Jena (Jena/Germany) \\ E-mail: erdem.ucar@uni-jena.de
}

1897'de Y. N. Klements tarafından keşfedilip 1899 'da ilk kez W. Radloff tarafından neşredilmesinin ardından Tuñuquq yazıtları, sayısız araştırmacının ilgisini çekmiş ve yazıtlar müstakil olarak birkaç kez neşredilmiş, yazıtlardaki sorunlu yerler hakkında çeşitli makaleler yayımlanmıştır.

Tanıtımını yapacağım çalışma Tuñuquq yazıtlarının en son neşridir. Yazıtın neşrini gerçekleştiren Cengiz Alyılmaz yıllardır Eski Türk yazıtlarının bulunduğu bölgelerde taşları yerinde inceleme firsatı elde eden ve onların epigrafik belgelendirmesi konusunda uzmanlaşan araştırmacılardan biridir. Alyılmaz'in yıllar içinde yaptığı saha araştırmalarının bir neticesi olarak Bilge Tonyukuk Yazıtları isimli eser gün yüzüne çıkmıştır.

Yazar, eserinin Ön Söz'ünde çalışmasının çıkış noktasını kısaca şöyle özetlemektedir: "Çalısmanın temeli her şeyden önce alanda (bu satırların yazarının yazıtların bulunduğu bölgede) uzun yıllar boyunca sabır ve özveriyle yaptığı epigrafik belgelemelere ve bu belgelemeler sonucunda elde edilen bilgilere ve bulgulara dayanmaktadır." (s. VI)

Giriş bölümünün başında Eski Türk yazıtlarıyla ilgili çalışmalar hakkında bilgiler verildikten sonra (s. 1-8), Tuñuquq yazıtları hakkında Türkiye'de ve yurtdışında yapılan çalışmalardan (s. 9-36) bahsedilmiştir.

\footnotetext{
ORCID ID: 0000-0002-0039-9619.
} 


\section{0}

1. Bölüm'de ilk olarak Tuñuquq'un bilge, Toñuquq ve Boyla Baġa Tarqan şeklindeki ad ve unvanları hakkında ayrıntılı malumat verilmiştir (s. 39-62). Bunlar içinde şimdiye değin kökeni üzerinde en çok tartışılanı Toñuquq adı/unvanı olmuştur. Yazar, ad hakkında şimdiye kadarki önerileri sıraladıktan sonra Çinli tarihçi Luo Xin'in önerisinin doğru olabileceğine inandığını söylemektedir. Xin'e göre Toñuquq adının ilk parçası olan ton 'bir unvanı' ve yuquq da 'bir görevi' bildiriyor olmalıdır. Yazar, pek çok kişi gibi Boyla Baġa Tarqan'in Tuñuquq'un bir unvanı olduğunu kabul etmektedir, ancak bu konuda Rybatzki'nin (1997: 84-86, dip. 229) farklı bir görüşü vardır. Eski Türkçe ile Moğolcadaki unvanlar konusunda uzmanlaşan Rybatzki, Boyla Baġa Tarqan'ın başka bir şahıs olabileceğine ihtimal vermiştir.

Daha sonra Boyla Bag்a Tarqan Bilge Toñuquq'un kişilik özellikleri üzerinde durulmuştur (s. 63-74). Bunun ardından, Ekleme başlığı altında (s. 75-91) Runik harfli 6 satırlık Oldenburg fragmanı olarak bilinen ve Tuñuquq ile ilgili olduğu düşünülen parçanın yeni bir neşri sunulmuştur. Erdal ve Chen, Oldenburg fragmanındaki tarihlerin (9. ayın 25'i ve 12. ayın 18'i) Çin kaynaklarıyla uyuştuğunu düşünerek fragmanı Tuñuquq yazıtının 3. ve 6. satırları arasında anlatılan olaylarla ilişkilendirmek istemiştir (2017: 111-112). Oldenburg fragmanının mevcut hâlinin hiçbir yerinde bir şahıs adının geçmediği görülüyor. Fragmanda tarihi gösteren yerlerin bir kısmı da yıpranmıştır. Dolayısıyla, bu fragmanın gerçekten Tuñuquq ile ilişkili olup olmadığı bence tartışma konusudur. Bunun ardından, Tuñuquq'un adının geçtiği Uygur harfli U 01a (T II $K$ 173) numaralı parçanın neşri Erdal ve Chen'in çalışmasından (2017) faydalanılarak verilmiştir. Burada Uygur harfli parça hakkında daha önce yapılan çalışmalardan da bahsedilmiştir. Zikredilen çalışmalara parçanın neşrinin sunulduğu Clark 2017 (125-126) de eklenmelidir. Son olarak, Tuñuquq ile ilgili XIV. yüzyıla ait Çince bir belgenin aslı ve tercümesi sunulmuştur. Sonuçta, okuyucu Tuñuquq ile ilgili tarihî kayıtları kitapta toplu olarak görebilmiştir.

1. Bölüm'ün üçüncü kısmında Tuñuquq'un mensup olduğu boy ve damgası üzerinde durulmuştur (s. 93-109). Buna göre, çeşitli arkeolojik ve tarihî bilgilerle desteklenerek Tuñuquq'un muhtemelen Tola irmağı çevresinde yaşayan 僕骨 Pugu (Bugu) boyuna mensup olduğu belirtilir. Ardından Tuñuquq'un ve boyunun damgası çeşitli görsel malzeme ile okuyucuya tanıtılmıştır. 


\section{ग(৫)}

2. Bölüm'ün başında Bilge Toñuquq yazıtları ve anıt mezar kompleksinin adlandırılmasından kısaca bahsedilmiş (s. 113-114), R. Giraud gibi bazı Türkologların yazıtların bulunduğu yeri esas alarak onları Bain-Tsokto olarak adlandırdığı söylenmiştir. Bunun hemen ardından şimdiye değin henüz kesin olarak çözüme kavuşturulamayan bir mesele olarak kalan yazıtların dikiliş tarihi konusu ele alınmıştır (s. 115-120). Yazıtların üzerinde tarihî bir kayıt bulunmadığ için araştırmacılar yazıtların dikiliş tarihi üzerine sadece bazı tahminlerde bulunmak zorunda kalmıştır. Yazar, daha önce kabul ettiği 732-734 tarih aralı̆̆ı fikrinden artık vazgeçtiğini itiraf etse de (s. 115, dip. 95), Tuñuquq yazıtlarının dikiliş tarihi hakkında bir fikir ileri sürmemiş, daha önce ileri sürülen görüşleri özetlemekle yetinmiş, ama Tuñuquq yazıtlarının Kül Tégin yazıtına cevap olarak yazıldığı fikrine şiddetle karşı çıkmışırı. Burada, Tuñuquq yazıtlarının dikiliş tarihi hakkında Chen'in ve Kaya'nın dile getirdiği son görüşlere de yer verelim. Chen, yazıtların 716 yılı sonbaharında görevden el çektirildiği esnada Bilge Qaġan'a kendisini affettirmek için Tuñuquq tarafından diktirildiği kanaatindedir (2021: 146). Kaya da kısmen aynı fikirdedir. Tuñuquq yazıtlarının en geç 717 baharında tarihe not bırakmak amacıyla Tuñuquq tarafından diktirildiğini düşünmektedir (2021a: 266).

2. Bölüm'ün üçüncü kısmında Tuñuquq yazıtlarının bulunduğu anıt mezar kompleksi incelenmiştir (s. 121-180). Anıt mezar kompleksi üzerinde yapılan çalışmalardan bahsedilmiş ve kompleks içinde yer alan sunak masalarının, heykellerin, balbalların ve diğer malzemelerin resimleri verilerek anıt mezar kompleksinin tamamı okuyucuya daha yakından tanıtılmıştır. Bilhassa, anıt mezar kompleksinin hazırlanan taslak planlarının (s. 136-139) kompleksi ziyaret edemeyen okuyucuya faydalı olacağı şüphesizdir. Anıt mezar kompleksi hakkında yazarın bir tespiti ise oldukça önemli olmakla beraber epey de kaygı vericidir:

Türk yazıtlarının, anıt mezar komplekslerinin ve kurganlarının bulundukları bölgelerde (hiçbir resmi başvuruda bulunmadan, izin ve tedbir alınmadan) arkeolojik kazı (!) yapılması ise kabul edilebilir bir durum değildir. Türk kültür ve uygarlığının ölümsüzlük eserlerine büyük oranda zarar veren bu izinsiz kazılarda (!) ortaya çıkartılan buluntuların neler olduğu ve hangi müzeye veya hangi yetkili makama teslim edildiğine dair de hiçbir kayıt ne yazık ki bulunmamaktadır. (s. 134) 
2. Bölüm'ün dördüncü kısmında Tuñuquq yazıtlarının bugünkü fizikî durumu hakkında bilgi verilip yazıtlar ayrıntılı olarak tavsif edilmiştir (s. 181262). Yazıtlar, iki taştan oluşmaktadır. Kağanlık yazıtlarından farklı olarak Tuñuquq yazıtlarındaki iki taşın altında da kaide bulunmaz. Taşların sekiz cephesi toplam 62 satırlık bir metin içermektedir. Taşların üzerindeki metnin sırası ve satır sayısı şu şekildedir:

I. Taş (35 satır): Batı yüzü (1-7. satırlar) $\rightarrow$ Güney yüzü (8-17. satırlar) $\rightarrow$ Doğu yüzü (18-24. satırlar) $\rightarrow$ Batı yüzü (25-35. satırlar)

II. Taş (27 satır): Batı yüzü (36-44. satırlar) $\rightarrow$ Güney yüzü (45-50. satırlar) $\rightarrow$ Doğu yüzü (51-58. satırlar) $\rightarrow$ Batı yüzü (59-62. satırlar)

Yazıttaki her cephenin ölçülerinin ve aslının daha iyi görülebilmesi adına her cephenin yeniden çizilen taslak resimleri sayesinde okuyucu yazıtların orijinalini zihninde daha iyi canlandırabilecektir.

3. Bölüm'ün başında Tuñuquq yazıtlarında kullanılan Runik harflerin listesi harflerin farklı varyantları da gösterilmek suretiyle sıralanmıştır (s. 265-268). Birleşik Yazılan ve İki Ayrı Ünsüzü Karşılayan Karakterler ve Ses Değerleri başlıklı tablonun içinde /y/ ve /ñ / ünsüzlerinin de zikredildiği görülüyor, ancak bu harflerin iki ayrı ünsüzü göstermesi sözkonusu değildir, zira Eski Türkçede /y/ ve /ñ / ünsüzleri bağımsız birer ayrı sesbirimdir.

3. Bölüm'ün ikinci kısmında, Bilge Tonyukuk Yazıtlarının Epigrafik Belgelemelerinde Uygulanan Yöntemler başlı̆̆ı altında (s. 269-270) taşların üzerindeki harflerin tespitinde izlenen yöntem açılanmıştır. Yazar, asırlar içerisinde taşların tahrip olması nedeniyle taştaki harfleri doğru tespit edebilmek için fotogrametrik yöntem ile parmakla yoklama yöntemini kullanmak zorunda kalmıştır. Yazar, taşların üzerindeki harfleri seçerken harfleri farklı kodlarla gösterip yazıtların üzerindeki harflerin mevcut durumunu okuyucuya net bir şekilde göstermiştir. Mesela, bugün sağlam olan harfler siyah ile işaretlenirken, dökülmeye yüz tutmuş olanlar mavi, üzeri boyanmış harfler turuncu, yağlı kısımlar sarı alt çizgi, alttan ve üstten kırılan harfler yeşil, Radloff Atlası'nda o dönemde dökülmüş olanlar kırmızı nokta, yok olmak üzere olanlar pembe, yazıttan tamamen kopanlar yükseltilmiş kırmızı ve tamamen yok olanlar ise kırmızı ile işaretlemiştir. 
3. Bölüm'ün üçüncü kısmında, Bilge Tonyukuk Yazıtlarının Çeviri Yazılarının Hazırlanmasında Uygulanan Yöntemler'den bahsedilmiștir (s. 271-275). Yazıtların Latin yazısına aktarılması hususunda uygulanan yöntem açıklanırken transcription terimi biraz farklı yorumlanmıştır. Mesela, yazar yazıya geçirme'yi (transcription) "sözlü dile ait ögelerin yazıya aktarılmasını karşılayan bir terim" olarak tanımlamakta ve "Bilge Tonyukuk Yazıtları'nin metinleri zaten yazılı dile/grafik dile ait oldukları için bir başka alfabeye (başta Latin alfabesi olmak üzere) aktarılirken bu aktarma işi için yazıya geçirme (transcription) teriminin kullanılması[nın] doğru" olamayacağını, çünkü “yapılan iş[in], yazıya geçirme değil; yazı çevirimi” olduğunu ifade etmektedir (s. 271, dip. 136). Yazarın bahsettiği "sözlü dile ait ögelerin yazıya aktarılmasını karşılayan terim" aslında transcription değil, phonetic transcription'dur, zira phonetic transcription'un dilbilimdeki anlamının "system of symbols used for the written notation of spoken language" (Bussmann, 1996: 894) olduğu bilinmektedir. Tarihî metinleri inceleyen filologların phonetic transcription'u kullanabileceği zaten düşünülemez. Tarihî metinleri inceleyenlerin kullanacağı uygulamalardan biri olan transcription, yani yazıçevrim veya yazarın tercih ettiği terimle ifade edersek yazıya geçirme "process and result of rendering a text in one script" (Bussmann, 1996: 1212) olarak tanımlanmaktadır.

Benim harfçevrim ile adlandırmayı tercih ettiğim terim için ise yazar yazı çevirimi terimini benimsemiştir. Yazı çevirimi, "yazılı dile/grafik dile ait ögelerin bir başka yazıya/alfabeye aktarılması" olarak tanımlanmış ve yazı çevirimi'nde "bir alfabeyle yazılan metnin diğer bir alfabeye aktarlması söz konusu” olduğu belirtilmiştir. Burada tanımı verilen ve yazı çevrimi olarak adlandırılan terim transliteration, yani harfçevrimdir. Harfçevrimi veya yazı çevrimi tarihî metinleri çalışanların kullanacağı uygulamalardan biridir. Yazar, yazı çevrimi'nin üç farklı şeklinden bahsetmektedir. Bunlardan yorumsuz yazı çevirimi ve yorumlu yazı çevirimi terimlerinde Gemalmaz'ın makalesinden (2001: 25-37) faydalanıldığı, uyarlanmış yorumlu yazı çevirimi'n ise literatüre yazar tarafından kazandırıldığ söylenmiştir (s. 271, dip. 137).

Yazar, yorumsuz yazı çevirimi'nde "iki alfabe arasinda birebir harf ve noktalama denklikleri” oluşturulduğundan (s. 271) bahsetmektedir, ancak neşirdeki uygulamanın bu ilkeyle çeliştiği görülmektedir. Mesela, yazıtların 11. satırında <ẅlrtçlk> kelimesinin yorumsuz yazı çevirim'i ölrtçik, ama <tẅrksIrBwDN> kelimesinin yorumsuzyazı çevirim'i ise türksirḅoḍ̣ şeklinde yapılmıştır. İki ibarede 


\section{J(৫)}

ortak olan işaret $<\ddot{w}>$ olmasına rağmen, $<\ddot{w}>$ işaretinin yorumsuz yazl çevirimi'nin birinde ö, ötekinde ise $\ddot{u}$ ile gösterilmesi bir tutarsızlık oluşturmaktadır. Yine aynı satırda brye ve $\dot{y} r \dot{y} a$ kelimelerindeki $<\mathrm{A}>$ işareti ortaktır, ancak iki kelimedeki $<\mathrm{A}>$ işareti birinde yorumlanarak $\boldsymbol{e}$, diğerinde ise yine yorumlanarak $a$ ile gösterilmiştir (s. 324). Eğer Runik alfabe ile neşir alfabesi arasında birebir harf denkliği kurulacaksa aynı harfin hiçbir şekilde yorumlanmadan aktarılması beklenmektedir.

Eğer bir metnin yorumsuz yazı çevirimi'nde asıl metindeki harflerin birebir karşıllı̆̆ harfiyen [= yorumlanmadan] verildiyse ve yorumlu yazı çevirimi kısmında da metindeki harflerin karşllığı metnin tarihî dil özelliklerine göre yorumlanarak gösterildiyse, daha sonra uyarlanmış yorumlu yazı çevirimi'ne bence gerek kalmamaktadır.

Yazar, uyarlanmış yorumlu yazı çevirimi'nin zorunluluk hâlini almasının gerekçelerini şu şekilde özetlemiştir:

Benzer fonetik özelliklere sahip ünsüzleri karşılayan karakterlerin/harflerin o dönemde birbirlerinin yerlerine kullanılabilir olmaları,

Yazıcının metni/mesajı aktarmayı esas hedef olarak görmesi ve harflerin/karakterlerin yazılışlarına bu sebeple dikkat etmemesi,

Yazıcının alfabenin yazılış özeliklerini ve alfabeye ait kuralları yeterince bilmemesi,

Yazıcının metni taşa işlerken görevli ve anlamlı dil ögelerini (sözcükleri, sözcük gruplarını, ekleri vb.) karşılayan karakterleri belirlenmiş bir alana yerleştirebilme/sığdırabilme kaygısı vb. (s. 275)

Yani yazar uyarlanmış yorumlu yazı çevirim'i kısmında, yazıtlar Türkçesindeki standart imlâya aykırı olan orijinal metindeki yazımları değiştirip standart şekline uyarlamayı hedeflemektedir:

“Uyarlanmış yorumlu yazı çevirimi bir dilin ölçünlü yazım kurallarıyla o dilin kullanıcılarının kendilerine özgü yazım kuralları (tercihleri) arasındaki farkın daha iyi anlaşılabilmesini de sağlamaktadır." (s. 285)

Yazıtlarda, teklik III. şahıs iyelik eki $\{+$ sI(n)\}'daki $<$ s $>$ ve $<$ n>'lerin her zaman ince sıradan işaretlerle yazıldığı bilinmektedir (Tekin, 1980: 10-17). Yazar, bu yazımları standart yazıma uyarlamaya çalışmaktadır. Mesela, 12. satırdaki <YGwçIsI> (a) ýğuçıșı (s. 353) veya 41. satırdaki <YBGwsIn> ý(a)ḅ́guṣın (s. 370) 


\section{ग(৫)}

yazımları kalınlık incelik uyumuna sokularak okunmuştur. Ancak bu yazım özelliğini yazarın sıraladığı gerekçelerle açıklamak mümkün değildir. Dolayısıyla, bu tür yazımları uyarlanmış yorumlu yazı çevirimi ile göstermenin neşre bir fayda sağlamadığı açıktır. Üstelik yazar çok güzel bir şekilde Tuñuquq yazıtlarında aynı kelimenin farklı işaretlerle yazıldığı durumları liste hâlinde sunmuştur (s. 276-277). Ayrıca bir ikinci listede de standart yazımla uyuşmayan yazımları sıralayıp yorumlu yazı çevrimi başlı̆̆ı altında bunların standart yazımını göstermiştir (s. 278-285). Yazıtlardaki standart yazıma aykırı olan veya yazım yanlışı olması muhtemel olan yerleri iki listede de okuyucu kolaylıkla görebileceğinden, okuyucunun uyarlanmış yorumlu yazı çevirimi başlığı altında üçüncü bir kısma artık ihtiyacının kalmayacağı söylenebilir. Diğer taraftan uyarlanmış yorumlu yazı çevirimi başlığı altında sunulan neşrin yorumlu yazı çevirimi kısmına aktarılmasının mümkün olabileceğini de vurgulamalıyım.

Tuñuquq yazıtlarında en çok dikkati çeken yazım özelliklerinden biri /s/ve /ş/ ünsüzlerinin farklı işaretlerle gösterilmesidir. Bu konuda yazar şu tespitlerde bulunmaktadır:

Yazıcının birçok yerde kaynak alfabenin standart kuralları dışına çıktığı; özellikle kalın ve ince ünsüzleri karşılayan karakterleri birbirlerinin yerine kullandığı, ünlülerin yazımında da keyfi davrandığı görülmektedir. Bunun sebebini birkaç şekilde izah etmek mümkündür: Bu durum öncelikle yazıcının bazı karakterleri taşa kazarken yaşadığı güçlükten kaynaklanmış olabilir. Yani yazıcı taşa kazınması/işlenmesi zor olan bir harfin/karakterin yerine benzer fonetik özelliklere sahip olan ve taşa işlenmesi kolay olan bir harfi örneğin, ş $\left({ }^{\aleph}, \nsucc\right)$ yerine s ( $($ ) tercih etmiş olabilir. Nitekim Bilge Tonyukuk Yazıt'larına ait metinlerde geçen ve bünyelerinde ş $\left({ }^{\star}, \forall\right)$ sesini barındıran sözcüklerin (birkaç istisna dışında) söz konusu harfler s, s $(\psi, \mid)$ ile yazılmıştır. Bu yazımın tamamen bir lehçe/ağız farklılığından kaynaklandığını söylemek hakikaten güçtür. (s. 274)

Bu sorunu Róna-Tas (1987: 10) ve Stachowski (1998:391-399) hem Altayistik hem de grafemik açıdan farklı bir bakış açısıyla ele almıştır. Eserin kaynakçasında görülmeyen bu iki çalışmadaki görüşlerin incelenmesi belki yeni bir fikir oluşturabilir.

4. Bölüm'de yazıtların neşri bulunmaktadır (s. 305-402). Neşirde her cephenin neşrinin başında yazılı metnin içeriği hakkında açıklamalar yapılmış ve böylece okuyucunun metni daha iyi anlamasına imkân tanınmıştır. Neşirde, metnin okuma ve anlamlandırılması hakkında yazarın kendisine ait filolojik 
açıklama ve notlamaların fazla olmadığı dikkati çekmektedir. Yazıtların 6. satırındaki bülser, 8. satırındaki uçuq teg ve an [t]eg, 25. satırındaki ogrruqlatdım, 33. satırdaki yiyi ve 56. satırdaki bin tegi hakkındaki kısa açıklamalar (s. 289-300) dışında neşirde başka bir notlama bulunmamaktadır.

Yazarın bazı notlamaları hakkında kendi görüşlerimi de paylaşmak istiyorum.

Epigrafik incelemelerin neticesinde 6. satırda şimdiye değin çok tartışılan sözcüğün <bülsr> şeklinde yazılldığı tespit edilmiş ve kelime bülser 'bilse' şeklinde okunup bil- fiilindeki ünlünün dudak ünsüzü /b/'nin tesiriyle yuvarlaklaştı̆̆1 iddia edilmiştir (s. 293-294). Yazarın, taşın aslında kelimeyi <bẅlsr> şeklinde tespit etmesi çok önemli bir katkıdır. Bu nedenle kelimenin yorumlanmasında yazarın tespiti öncelikli olmalıdır, ancak onun bülser 'bilse' önerisini kabul etmek zordur, zira bil- fiilinin ünlüsünün yuvarlaklaşmasına Eski Türkçenin hiçbir metninde rastlanmamaktadır. Yazarın epigrafik tespitine dayanarak buradaki kelime <bülsr> olarak kabul edilmelidir. Daha önce Rybatzki'nin tespit ettiği üzere (1997: 45, dip. 105) böl- fiilinin cümlede 'ayırt etmek, tefrik etmek' anlamında kullanılmış olması mümkün olabilir, zira Eski Türkçede böl- fiilinin 'ayırt etmek, tefrik etmek' (Wilkens, 2021: 192a) anlamına Eski Uygurca metinlerde de rastlanmaktadır. Ancak bence bağlama en uygun okuma önerisi büyük oranda Tezcan tarafından (2010: 273-280) ilk kez dile getirilen, sonradan Yıldız (2013: 113-134) tarafından tamamlanan <bẅlsr> böl(e)s(e)r 'böğürse' okuma önerisidir. $\mathrm{Bu}$ teklifte önerinin Türk dillerinde tanıklanması da mümkün olmaktadır. Üstelik böle- 'bögürrmek' önerisi cümlenin fâilleriyle de gayet uyumludur.

8. satırda <YGmz : tgrA : wçwqtgrtI : bIz : 口 $\mathrm{g}: \mathrm{rtmz}$ :> şeklinde yazılan cümleler ve ikinci cümlede $\square$ şeklinde yer alan işaret sorunludur. Yazar, sorunlu işareti Yenisey yazıtlarında /y/ karşılığında olan harfle aynı olduğunu düşünerek ibareyi (a)y [t]eg 'avcı kuşlar gibi, akdoğanlar gibi' ile aktarmayı önermiştir (s. 291-292, 321). Sorunlu işaret hakkında ve cümlelerin $y(a) \dot{g}(1) m(1) z$ t(e)gr(e) uçuq t(e)g(e)rti biz eş(i)g $(e) r t(i) m(i) z$ "Düşman[lar]ımız etrafta ocak gibiydi. Biz [ise] eşik [veya kapı] gibiydik" veya $y(a) \dot{g}(1) m(1) z t(e) g r(e)$ uçuq $t(e) g(e) r t i ~ b i z$ $b(\ddot{u}) g(e) r t(i) m(i) z$ "Düşman[lar]ımız etrafta ocak gibiydi. Biz [ise onların] kenarı gibiydik" şeklindeki yeni iki yorumu için bk. Uçar, 2021c: 19-26. 


\section{Ј(৫)}

33. satırda şimdiye değin kişi olarak okunan sözcüğün taşın üzerinde yapılan inceleme neticesinde <ylyI > olduğu tespit edilmiş ve kelime cümledeki kullanımı esas alınarak yiyi 'artarda, birbiri ardınca, peş peşe, birbirini izleyerek' ile anlamlandırılmıştır (s. 295-296, 357). Kelime üç körüg yiyi kelti cümlesinde geçiyor. Yazarın bağlama dayanarak önerdiği anlamlandırma uygun görünüyor, ancak yiyi'nin yapısı izaha muhtaçtır. Yazar, daha önce yayımladığı makalesinde (2001: 14-15), yiyi kelimesinin 'sıralanmış, art arda, birbiri ardınca sık' anlamlarıyla ve yiyi, yigi ve cigi şekilleriyle hem Dîvânu Lugâti't-Türk ve Eski Uygurca gibi eski Türk dili yadigârlarında hem de günümüz Türk dillerinde geçtiğini ifade etmiştir. Yazarın bahsettiği Eski Türkçe yigi 'close, compact, a (tightly sewn) seam' sözünün tanıklanmamış *yig- fiiline dayandığ1 tahmin edilmektedir, krş. yigtür- 'sıkıştırmak, sıklaştırmak' (Clauson, 1972: 911a, 912a). Ancak bu kelime ile Tuñuquq yazıtlarında sadece bir kez geçen yiyi kelimesini yapısal bakımdan nasıl ilişkilendirilebileceği hakkında kesin bir kanaate ne yazık ki sahip değiliz. Kelimenin bir fiil kökü olması muhtemeldir. O zaman kelimenin sonundaki \{-(y)I\} ekini ünlü zarffiil eki olarak kabul etmek gerekiyor. Bu konuyu başka bir makalemde daha ayrıntılı ele alacağım için üzerinde fazla durmayacağım.

Bunlar dışında neşirdeki bazı okuma ve anlamlandırmalara da kısaca değinmek istiyorum:

Eski Türkçede kapalı /é/'li olduğu konusunda artık şüphe bulunmayan sözcüklerin neşirde /i/'li okunduğu görülmektedir. Muhtemelen, yazıtlardaki $<\mathbf{I}$ 'li yazım yazarı böyle okumaya itmiş olmalıdır. Daha önce Doerfer'in ortaya koyduğu üzere kapalı /é/ ünlüsü yazıtlarda $<\mathbf{I}>$ işaretiyle de temsil edilebilmektedir (1994: 108-132). Doerfer, yazıtlarda kapalı /é/'li sözlerin listesini de vermiştir. Dolayısıyla neşirdeki timiş (2. satır), ilteriş (7. satır), vd. gibi okunuşların kapalı /é/'li olarak okunması gerekmektedir.

1. satırdaki tabg்aç éline qulıntım cümlesi "Çin ülkesinde doğdum" ile Türkiye Türkçesine aktarılmıştır (s. 309). Burada birkaç sorun gözüküyor. Cümledeki él kelimesinin Eski Türkçedeki anlamlarından birinin 'siyasî idare' olduğunu Giraud (1961: 66) çok önceden fark edebilmiştir. Ayrıca éline'deki $\{+\mathrm{kA}\}$ ekinin süreci ifade eden zamansal işlevini de ilk kez Nauta tespit etmiş ve éline'yi doğru çevirmiştir: 'während des chinesischen Reiches/der chinesischen Herrschaft 


\section{J()}

(Ausdruck der Zeitdauer)' (1969: 309). Clauson'un 'grew up for (i.e, as a subject of) the Chine Empire' (1972: 623a) şeklinde tercümesinin de yanlış olmadığını belirtmeliyim. Ayrıca krş. Chen, 2021: 155, dip. 3. $\{+\mathrm{kA}\}$ ekinin süreci ifade eden zamansal işlevini qulın- fiili ile çok daha net bir şekilde anlayabiliyoruz. Aynı kullanım Ongi yazıtında rastlanmaktadır: qapġan élteriş qagàn élize qulındım (Doğu 4). Tuñuquq'un "Çin idaresi sürecinde büyüyüp yetiştiğinden" bahsetmesi, kendisinin Çin'i iyi tanıdığını vurgulaması adına dikkate değerdir. Sonuç olarak, ben özüm tabgáç éline qulıntım cümlesinin "Kendim [Türk halk1] Çin idaresindeyken büyüdüm" şeklinde aktarılması doğru olacaktır. Diğer taraftan, $\{+k A\}$ ekinin süreci ifade eden işlevine 58. satırda da rastlanmaktadır: türük bilge qaġan élige bititdim “Bilge Qaġan'ın idaresindeyken [yazıtlarımı] yazdırttım”. \{+kA\} ekinin bu işlevine dikkat edilirse, Tuñuquq yazıtlarının dikiliş tarihinin Bilge Qag̉an'ın iktidarı bıraktığı 734 tarihinden önce olabileceği bilgisine de kolaylıkla ulaşabilir.

Yine, 1. satırdaki $<q^{1} I l n t m>$ kelimesinde Radloff'un erken dönemde fark ettiği üzere (1899: 28), taşa hakkeden kişi bir yazım hatası yapmıştır ve doğru yazım $<q^{1} I L n t m>$ şeklinde olmalıdır. Ancak neşirdeki yorumlu yazı çevrimi'nde veya uyarlanmış yorumlu yazı çevirimi'nde (s. 309) harf kalın sıradan $<$ L> ile gösterilecekken, ince sıradan <l> ile göstermiştir.

2. satırdaki türk bodun qanın bulmayın kısmı "[Son yıllarda Türk halkı hanını bul[a]mayınca (hansızlığın/kağansızlığın ne demek olduğunu anlayınca)" ile aktarılmışır (s. 310). Buradaki <BwLmYn> kelimesi sorunludur. Kelimedeki ikinci işaret olan $<\mathbf{w}>$ harfinin /o/ veya /u/ ünlülerini karşılaması fiilin bol- veya bul- olarak iki farklı şekilde okunabilmesine neden olmaktadır. Bunlardan hangisi uygundur? Radloff un qanın bolmayın 'nicht mit seinen Chanen (im Einverständnisse) war' (1899: 2-3) şeklindeki okuma ve anlamlandırma önerisi uzun müddet sorgulanmamıştır. Nihayet Giraud 1961'de $(53,59,67)$ ve Gabain 1974’te (§ 234) ilk kez bulmayın ‘bulmadığı için’ önerisi ileri sürülmüştür. Yazarın bulmayın'ı 'bulmak' fiili ile ilişkilendirmesi doğru olmuştur, ancak kelimeyi 'bul[a]mayınca' şeklinde aktarması biraz şüphelidir, zira \{-(X)yIn\} zarffiil ekinin '-IncA' karşıllğıında zamansal bir işlevinin olduğunu gösteren bir delile sahip değiliz, krş. Erdal, 2004: 316-317. Yazıtlarda birkaç kez tanıklanan ekin işlevinin pek de belirgin olduğu söylenemez. 


\section{Ј(৫)}

3. satırdaki <ültms> yazımındaki ibare öl témiş şeklinde okunup 'öl demiş' ile anlamlandırılmıştır (s. 311). Bu ibarenin ölütmiş 'öldürmüş’ şeklinde okunmasına da rastlanmaktadır, zira bu yorumu benimseyenlere göre öl- fiilinin $\{-(\mathrm{X}) \mathrm{t}-\}$ ekli ettirgen gövdesi cümleye daha uygundur. Ancak Eski Türkçede ölfiilinin $\{-(\mathrm{X}) \mathrm{t}-\}$ ekli ettirgen gövdesine başka bir metinde rastlanmamıştır. Yazarın epigrafik belgelemelerinde $<$ ẅltms $>$ kelimesinin geçtiği yerin yakın plan resimlerine bakıldığında ikinci harf olan <l>'nin etrafındaki harflerden farklı olarak iki harfin arasına çok fazla bitişik yazıldığı görülmektedir. Sanki taşa kazıyan kişi <l> harfini sonradan eklemiş gibidir. Clauson, taşın resimlerine bakınca -ki o taşın aslını görmemiş̧i- bu tuhaflığı hemen fark etmiş ve yazıtta <l> olarak düşünülen harfin bir yarık olabileceğini düşünmüş, cümleyi tegri ötmiş erinç "Heaven, no doubt, abondoned you" (1972: 133a) şeklinde okuyup anlamlandırmıştır. Clauson'un <l> olarak düşünülen harfi bir yarık olarak değerlendiren tahmini yabana atılmamalıdır. Yazarın taşın aslından elde ettiği yakın plan resimlerde (s. 187-188) sorunlu ibare şu şekilde görülmektedir:

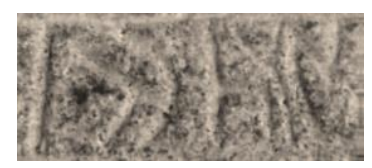

< ltlms> veya < ẅtms> ibaresinin öncesinde içikdük üçün 'tâbi olduğun için' vardır. Buna göre, içikdük üçün'ü gerekçe göstererek tegri bir eylem gerçekleştirmiştir. Clauson'un öt- için önerdiği 'vazgeçmek' eylemi bağlama gayet güzel uyuyor, ama fiilin Eski Türkçede bu anlamına rastlanmaması düşündürücüdür. Ben iki ihtimalin daha mümkün olabileceğini düşünüyorum:

1. Belki de tegriötmiş erinç cümlesindeki öt- fiili ‘buyurmak' gibi bir anlamda olmalıdır. Gerçi teyri 'gök' için öt- fiilinin kullanılmış olması biraz zordur, zira Eski Türkçede öt- fiilinin hiyerarşik olarak alttaki birinin yukarıya hitabında kullanıldığı bilinmektedir. Belki de öt- fiilinin hiyerarşik bağlamda kullanılması Kağanlık yazıtları döneminde henüz ortaya çıkmamıştı. Ya da buradaki öt- fiili ötün-'ün 'arz etmek' kökü olabilir ve anlamı da 'dilemek, arzu etmek' olmalıdır. $\mathrm{Bu}$ anlam da bağlama uygundur, zira tegri ötmiş erinç’ten sonra türk bodun ölti alqintı yoq boltı cümlesi gelmektedir. Yazıtlarda bunların tegri'nin isteğiyle gerçekleştiği anlatılmak istenmiş olabilir.

2. Metni taşa kazıyan kişi ibarenin başında sadece <I> yazmak istediği, ama hata yapınca oyduğu harflerde düzeltme yoluna gittiği tahmin edilebilir. 0 


\section{ग(๑)}

zaman buradaki ibare <Itms> étm(i)ş olmalıdır. Kağanlık yazıtlarında ét- fiilinin tegri ile beraber kullanılması için krş. üze türük tegrisi ıduq yéri subı ança étmiş (Kül Tégin, Doğu 10-11; Bilge Qaġan, Doğu 10).

3. satırda <türk : sIrBwDN> türk : sir bodun, 11. satırda $<$ türksIrBwDN> türk sir bodun ve 60., 61. ve 62. satırlarda <t ẅr ${ }^{\mathrm{k}} \mathrm{ksIrBwDN}>$ türük sir bodun ibaresinin 3., 11., 60. ve 61. satırlarda 'Türk [ve] Sir halkları' (s. 311, 324, 400, 401), ama 62. satırda ise 'Türk Sir halkı' ile aktarıldığ görülüyor (s. 402). Daha önce, Czeglédy'nin belirttiği üzere VII. yüzyılda Türk Türük (突厥 Tu-jue) ve Sir (薛 Xue) halkları 628'den beri birlikte Ötüken bölgesinde yaşamıştır (1962: 65-66). Dolayısıyla, yazarın ibareyi -bir yer hariç- 'Türk [ve] Sir halkları' şeklinde birbirinden ayırarak aktarması isabetli olmuştur.

Neşirde, $<\mathrm{w} q / \mathrm{q}^{\mathrm{w}}>$ ve $<\mathrm{w}^{\ddot{w}} / \mathrm{k}^{\ddot{w}}>$ işaretlerinin $<\mathrm{w}>$ ve $<\ddot{\mathrm{w}}>$ işaretleriyle beraber ilk hecede kullanıldığında kelimenin uyarlanmış yorumlu yazı çevirimi'nde ünlülerin çift olarak gösterildiği görülmektedir. Mesela, buuqqal (5. satır), köörür erti (1. satır), vd. Şimdiye değin yazıtları neşredenlerin okumalarında böyle bir uygulamaya rastlanmamaktadır. Böyle bir okuma önerisi kelimenin uzun ünlülü olduğu algısını oluşturmaktadır. Yazıtlardaki bu imlânın uzun ünlüleri belirlemede her zaman tutarlı ve istikrarlı bir delil sunduğu söylenemez. Mesela, küntüz kelimesi 12. satırda <kẅntz> şeklinde yazılırken, aynı kelime 52. satırda $<\mathrm{k}^{\ddot{w}} \ddot{w} n t z>$ şeklinde yazılmıştır.

5. satırdaki qag்an $m u<q^{1} \operatorname{ISYIn}>$ (s. 313), 6. satırdaki qag்an <qISDm> (s. 314), 11. satırdaki yoq $<q^{1} \operatorname{ISLm}>$ (s. 324) ve 21. satırdaki $y^{2}$ oq $<q^{1} \operatorname{ISLm}>$ (s. 338) ibarelerinde harfçevrimlerini gösterdiğim fiil hakkında şimdiye değin kesin bir sonuca ulaşılmamıştır. Yazar, fiili qış- ve quş- 'kılmak' şeklinde okumaktadır. Tekin, fiilin qul-'in kökü olan *ql'nın işteş çatısı olduğunu ileri sürmüştür (1994: 28; 2014: 89-90), ancak kendisinin de fark ettiği üzere işteş çatılı bir yüklemin fâilinin teklik I. şahıs zamiri ben olması epey şaşırtıcıdır. Yazıtlardaki bu fiili anlamaya çalışanların çoğunun son kertede ulaştıkları netice bu fiilin qul'kılmak' ile ilgili olabileceğidir. Belki de buradaki sorun Türk Runik yazısının menşei ile ilgilidir. Bu konuda Róna-Tas (1987: 10) ve Stachowski'nin (1998: 391399) tespitleri göz önünde bulundurulmalıdır.

7. satırdaki öküşök okunuşunda Ok enklitiği ek gibi değerlendirilmiştir. Ayrıca krş. özümök (6. satır), benök (7. satır), oloq (42. satır), birtimök (52. satır), vd. 


\section{ग(৫)}

Ok enklitiğinin yazıtlarda ve Eski Türkçede ekleştiğini gösteren bir delil olmamasına rağmen, Ok enklitiği neşirde ek gibi kabul edilmiştir. Enklitiğin kök şeklinde olduğu varsayılan varyantı da neşirde köök olarak okunmuş ve o da dizinde 'pekiştirme/kuvvetlendirme eki/edatı' olarak tanımlanmasına (s. 433434) rağmen ek gibi kabul edilmiştir. Aslında yazarın okuyuşuna göre Ok veya köök'ün nerede ek nerede edat olduğu tam olarak anlaşılmamaktadır. Tuñuquq yazıtlarında Ok enklitiğinin ince sıradaki varyantı hakkında daha geniş bilgi için bk. Uçar 2022: 135-147.

7. satırdaki çoġay quzın qara qumuǵ olurur ertimiz cümlesi “(Biz) Çogay'[ın] kuzeyi ile Karakum [arasındaki topraklarda konargöçer bir şekilde] oturuyorduk/yaşıyorduk" şeklinde aktarılmıştır (s. 315). Cümledeki olur- fiilinin nesnesi $\{+(\mathrm{X}) \mathrm{n}\}$ vasıta hâl ekli çoǵay quzı ile $\{+(\mathrm{X}) g\}$ yükleme hâl ekli qara qum yer adlarıdır. Cümlede olur- fiili nesne almaktadır, bu nedenle fiilin burada 'oturmak, yaşamak' anlamında düşünülmesi mümkün değildir. Buradaki olur- fiili 'bir yeri idaresi altına almak, yönetmek' anlaminda olup filin bu anlamına Eski Uygurcada da (Wilkens, 2021: 506b) rastlanmaktadır. Cümlenin şu şekilde aktarılması gerektiği kanaatindeyim: “Çuġay Quzı ile Qara Qum'u idare ediyorduk [hâkimiyet altına almıştık]".

$\mathrm{Bu}$ arada, Chen yazitlarda geçen Çuġay dağlarının 陰山 Yinshan olamayacağını, Çuġay adının aslının Çince 總材 Zongcai olmasına bakılarak kelimenin /u/'lu okunması gerektiğini ve bu dağların 山西 Shanxi'nin kuzeybatısındaki dağları gösterebileceğini söylemiştir (2021: 21-25).

9. satırdaki <TwyRAsmg> togra semig'teki togra sem şahıs adı olarak kabul edilmiştir (s. 322), ama yanılmıyorsam ilk kez Geng'in semig (< semi+g (?)) için önerdiği Çince 司馬 sima 'minister of war' teklifi muhtemelen doğru olmalıdır (2005: 109). Aynı tespit daha sonra Rykin ve Telitsin tarafindan da dile getirilmiştir. Onlar Çince 司馬 sima'nın yazıtlardaki <smg> yazımına bakarak kelimenin kökünün sime $\sim$ sima $\sim$ sıma şeklinde olabileceğini, kelimede $\{+(\mathrm{X}) g\}$ yükleme hâli ekinin bulunduğunu ve unvanın 'a 2nd- or 3rd-level executive officer found in most military Guards (wei) stationed at the dynastic capital' anlamına gelebileceğini ifade etmiştir (2020: 298-299).

11. satırdaki türk sir bodun yérinte idi yorımazun usar idi yoq qışalım cümleleri "Türk [ve] Sir halk[larının] yerinde [yurdunda] hiç kimse yaşamasın, mümkünse 


\section{ग(৫)}

[onları] büsbütün yok edelim" (s. 324) ile aktarılmıştır. Burada ilk idi kelimesine 'hiç kimse' anlamı verilmesi mümkün değildir, zira idi Eski Türkçede 'asla, hiçbir surette' anlamına gelen bir kuvvetlendirme zarfıdır. Bu kelimeyle eşyazımlı olan diğer idi ise 'master, owner' anlamındadır (Clauson, 1972: 41a-42a). Bu cümlenin fâili tam olarak fark edilemediği için hiç kimse fâil olarak düşünülmüş olmalıdır. Bence ilk cümlenin fâili ve ikinci cümlenin nesnesi 9. satırdaki azqıña Türk 'azıcık Türk [topluluğu]' olmalıdır. 9. ve 11. satırlar arasında dolaylı anlatımlar olduğu için veya Tuñuquq başkalarının sözlerini aktardığı için cümlenin fâili kolayca fark edilememektedir. Bu arada yazarın 11. satırdaki yort- fiiline 'yaşamak' anlamı vermesi isabetli olmuştur, ancak bence 9. satırdaki yorı- da aynı anlamda olmalıdır. 9.-10. satırdaki azqıña Türk yorıyur ermiş cümlesi "Çok az [sayıda olan] Türk[ler gün geçtikçe artıyor ve ekonomik bakımdan da] ilerliyor[lar]mış" şeklinde aktarılmıştır (s. 322-323). Cümlenin fazladan eklemelerle aktarılmasına gerek yoktur. Cümlenin "Azıcık Türk [topluluğu] yaşıyormuş” şeklinde kısaca aktarılması yeterlidir. Sonuç olarak, türk sir bodun yérinte idi yorımazun usar idi yoq qışalım cümlelerinin “Türk [ve] Sir halklarının ülkelerinde (= Ötüken) [azıcık Türk topluluğu] asla yaşamasın, mümkünse [onları = azıcık Türk topluluğunu] tamamen yok edelim" şeklinde aktarılmasının doğru olabileceğini düşünüyorum. Bu önerim bağlama da gayet uygundur, zira Tuñuquq bu meşum istihbarî bilgiyi duyup düşmanlarının böyle düşündüğünü öğrenince gece uyumayı gündüz oturmayı bırakmıştır.

Neşirde, yel- ile onun ettirgen gövdesi yeltür-'ün anlamlandırmasında sorunlar bulunmaktadır. 26. satırdaki qaǵan yelü kör témiş cümlesi "Kağan [askerlere] atlıları yel gibi (dörtnala) sürün demiş" ile aktarılmış ve dizinde yelü kör- '(atı) dörtnala sürmek, koşturmak' ile anlamlandırılmıştır (s. 350, 447). 27. satırdaki yelü bardımız 'yel gibi gittik' ile aktarılmış ve dizinde yelü bar-'a 'yel gibi gitmek, çabucak gitmek' anlamı verilmiştir (s. 351, 447). Aynı şekilde 54. satırdaki yaraqlíg yag்ı yeltürmedim cümlesi "Silahlı düşmanları Türk halkının arasına sokturmadım" ile aktarılmış, dizinde yeltür-'e 'koşturmak, dolaştırmak, sokmak' anlamı verilmiştir (s. 390, 447). Eski Türkçede yel- fiili 'hızlı gitmek' anlamında değil, aksine 'tempolu, ama yavaş gitmek, tırıs gitmek' (Clauson, 1972: 918a) anlamindadır. 34. ve 52. satırlardaki yelme (< yel-me) kelimesi de muhtemelen yel- fiilinden türetilmiştir (Erdal 1991: 316). Eski Uygurcada yeliş (< yel-iş) sözü 'tırıs' anlamıyla (Wilkens, 2021: 882a) tanıklanmıştır. Clauson, yeltür-'ü yel- 
fiilinin ettirgen gövdesi olarak kabul etmesine rağmen, yeltür-'e 'to make (someone) hurry' anlamı vermiştir (1972: 923b). Bence Tuñuquq yazıtlarının 54. satırındaki yeltür-'ün anlamı 'atı yavaşça sürerek ilerletmek' olmalıdır. Clauson'un yel- ve yeltür- için verdiği 'atı hızlı koşturmak' anlamı Orta Türkçe dönemine aittir. Eski Türkçede yel-'in anlamı için birinci başvuru kaynağımız olan Kaşgarînnin sözlüğündeki şu örnek ve onun Arapça karşllı̆̆ bilhassa önemlidir: atlig yeldi "Süvari atı tırıs sürdü”. Kaşgarînnin yel- için verdiği Arapça karşl1ıklar xabba ve ahżara'dır (Dankoff-Kelly, 1984/II: 472 [182]). Krş. Arapça xabba 'a kind of run, with wide steps, but falling short of that i.e. a quick pace, or a certain pace which is not quick or a pace of a horse, and of a camel, in which he remores both his right legs together and both his left legs together; i.e. an amble: or in which a horse rests on his right and left fore legs alternately, and in like manner on his kind legs, quickness' (Lane, 1865/II: 692b) ve Arapça ahżara 'to run, to trot (of a man or horse)' (Lane, 1865/II: 589b). Tırıs yürüyüşü atın koşmayıp hızlı tempoda sekerek yürümesine verilen addır. Bu nedenle yel-fiilinin 'dörtnala koşmak' ile anlamlandırılması doğru olamaz. Neticede, 26. satırdaki qaǵan yelü kör témiş cümlesinin "Kağan, atı yavaşça sürmeye bak demiş" şeklinde anlamlandırılması gerekiyor, zira kör-fiili kendisinden önceki ünlü zarffiil ekiyle beraber yardımcı fiil olarak kullanıldığında 'denemek, bir işin yapılacağını garanti etmek' (Wilkens, 2021: 408a) gibi bir anlama gelmektedir. 27. satırdaki kün yme tün yme yelü bardımız cümlesinin "Gece gündüz demeden tırıs pozisyonda atları sürdük" şeklinde anlamlandırılması daha doğru olacaktır. Bir atın uzun mesafede en randımanlı gideceği yürüme pozisyonunun tırıs gitmek olduğuna bakılırsa bu anlamlandırmanın doğruluğu kendiliğinden anlaşılacaktır. Son olarak, 54. satırdaki bu türük bodun ara yaraqlíg yag்ı yeltürmedim cümlesinin "Silahlı düşmanların Türk halkı arasında atlarını salına salına sürmesine izin vermedim" şeklinde aktarılması gereklidir.

28. satırın başı tahrip olmuştur ve sadece $<\mathrm{N}>$ harfi korunabilmiştir. Yazar,

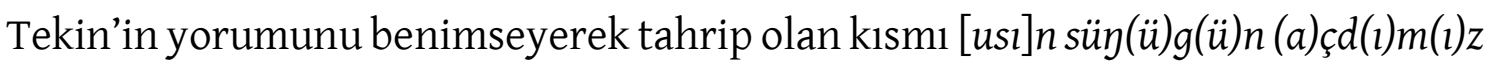
ile tamir edip okumaktadır (s. 352). Bu önerinin mantıklı olmadığını bir makalemde izah etmiş ve tahrip olan kısmin $[q u l(1) \mathcal{c}(1)] n$ süy(ü)g(ü)n $(a) c ̧ d(\imath) m(1) z$ ile okunması gerektiğini teklif etmiştim (2021a: 1-9). Türk Kağanlığı ordusunun uyandırma servisi gibi bir vazifesinin olmadığı fikrinde hâlâ ısrar ediyorum. 


\section{ग(৫)}

30. satırdaki ben ebgerü tüsseyin tédi cümlesi "Ben eve döneyim dedi" (s. 354) şeklinde aktarılmıştır. Buradaki \{+gArU\} tüş- fiili dikkat çekicidir. Muhtemelen Clauson'un "I am going home (to stay there)" şeklindeki önerisi (1972: 560a) doğrudur. Ayrıca bk. Awğali, 2011: 275-276. Krş. Azerbaycan Türkçesi düş- 'bir yerə gələrək orada müvəqqəti yerləşmək, qalmaq, müsafir olmaq, qonaq olmaq' (Orucov, 2006/I: 724b).

34. satırdaki <nçAYIDms> yazımı ança ayıdmış olarak okunmuş ve 'böyle söylemiş' ile aktarılmıştır (s. 358). Daha önce yazdığım bir makalede bu okumanın mümkün olamayacağını ve ibarenin ança ayu ıdmış 'tam ve eksiksiz olarak şöyle söylemiş’ şeklinde okunup anlamlandırılması gerektiğine işaret etmiştim (2017b: 31-38). Bu önerimin doğruluğu konusunda hâlâ aynı kanaati taşıyorum.

Yine 34. satırdaki < ẅzwl> yazımı üz ol olarak okunmuş ve 'art niyetlidir' ile aktarılmıştır (s. 358). Daha önce yazdığım bir makalede Eski Türkçede ve Türk dillerinde 'nefret, öfke, kin' anlamına gelen ör öz [ür üz] diye bir kökten bahsetmiş̦tim (2017a: 1-11). Bağlama bakıldığında bahsettiğim öz üz kelimesinin buraya uygun olduğunu söyleyebilirim.

38. satırdaki tegri umay ıduq yér sub basa bérti erinç cümlesi "[Çünkü] Tanrı, Umay (melekler) kutsal yer[lerin ve] su[ların sahipleri onların] basiretlerini bağladı" ile aktarılmıştır (s. 367). Yazarın burada basa bérti için önerdiği 'basiretini bağladı' anlamlandırması yeni bir yorumdur, ancak bas- fiilinin bu yorumla uyuşabilecek herhangi bir anlamı Eski Türkçede tanıklanmamıştır. Aslında yazıtlarda 'basiret bağlamak' diye bir kavrama da rastlanmaz. Yazıtların bu kısmının bağlamı aslında yeterince açı değildir. Belki de buradaki <BSAbrtI> ibaresi basa bérti şeklinde değil de $b(a) s ̧$ (e)b(i)rti 'baş çevirdi' şeklinde okunmalıdır. Bu anlamda ebir- fiilinin ikinci hecedeki ünlüsünün yazılmaması için krş. 28. satır. Bu konuyu başka bir yazımda ayrıntılı olarak ele alacağım için üzerinde fazla durmayacağım.

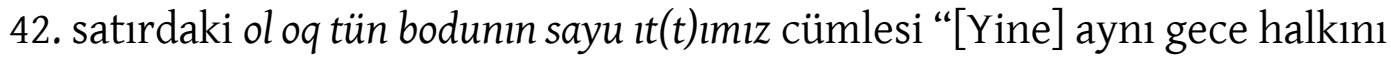
[bağışlayıp] geri gönderdik” ile aktarılmıştır (s. 371). Bağlama bakıldığında Clauson'un çevirisi makul gibi görünüyor: "We went (envoys ?) to all their peoples" (1972: 858b), ancak cümleden ne gönderildiği tam olarak anlaşılmıyor. Cümlenin devamına bakıldığında Clauson'un düşündüğü gibi gönderilenin 'elçi' 


\section{J(৫)}

olması oldukça muhtemeldir, ancak bence buradaki it- fiili 'göndermek' anlamında değil, 'salmak, serbest bırakmak' anlamında olmalıdır. Dolayısıyla ttfiilinin bu anlamına göre nesnesi bodunin (< bodun+1n) olmaktadır. Fiilin bu anlamına Eski Uygurcada da rastlanmaktadır. Mesela Altun Yaruq'taki éçilerin ıdıp 'abilerini serbest bırakıp' (Kaya, 2021b: 596) tanığı Tuñuquq yazıtlarındaki yapıyla birebir örtüşmektedir. Buna göre, ol oq tün bodunin sayu $\imath t(t) \imath m ı z$ cümlesinin "Işste o gece halk[lar]ın her birini serbest bıraktık" şeklinde aktarılabileceğine inanıyorum.

44. satırdaki beylig Ek tag்ıg ibaresi "[ve adeta insana] huzur [veren] Ek Dağı'nı" ile aktarılmıştır (s. 373). Yazarın düşündüğü anlamda bẹlig diye bir kelimeye Eski Türkçede rastlanmaz, ama benilig 'joyful, happy’ (Clauson, 1972: 770a) diye bir kelime vardır ve muhtemelen 44 . satırda <bylg> şeklinde yazılan kelime beyilig şeklinde okunmalıdır. Aslında Ek tağ'ın tam olarak nereyi gösterdiği konusu da tartışmalıdır (Aydın, 2006: 83-94). Beyilig Ek tä’’ın özel bir yer adı olması oldukça muhtemeldir, zira begilig'i burada 'joyful, happy' gibi bir anlamda kabul edecek olursak bunun dağı niteleyen bir özel ada dönüştüğünü düşünmek de mümkün olabilecektir.

45. satırdaki tezik kavim adı 'Arap' halkı olarak anlaşılmıştır (s. 377, 441). Tuñuquq yazıtlarında Tezik kavim adının 'Arap' halkını gösterdiği şüphelidir. İranlılar, en yakın komşusu olan Arapların Tayy kabilesinin adını bütün Araplara teşmil ederek Tācìk Tāzìk şeklinde adlandırmıştı, ancak bu konuda Barthold'un önemli bir dikkati gözden kaçırılmamalıdır (Barthold 1979: 616b; Fragner, 2000: 62a). İranlılıar Müslüman olunca Arap adı alıyordu. Tuñuquq yazıtlarının yazıldığı VIII. asırda Türklerin münasebet kurduğu halk muhtemelen Müslüman olan İranlılardı. Bu nedenle yazıtlardaki Tezik kavim adının Araplar olduğu konusunda kesin bir yargıya varılması biraz zor görünmektedir.

47. satırın başındaki tinsi og̉lı'nın fazlalık olduğu çok bellidir (Tekin, 1994: 49). Bu nedenle uyarlanmış yorumlu yazı çevirimi kısmında (s. 379) tinsi oǵlı'nın metinden çıartılması gerekmektedir.

50. satırdaki yag̉ıçısı 'komutanı' ile aktarılmıştır (s. 382). Buradaki yaġıçı sözünün \{+çI\} ekini almasına bakılarak kelime ‘komutan’ anlamında düşünülmüş olmalıdır, ancak \{+çI\} eki her zaman bir meslek adını göstermez. Mesela, armaqçı (< armaq+çı 'hilekâr'), baş̧̧ı (< baş+çı 'önder'), vd. Clauson, yag̉ıçı için 'mücadeleci, 
kavgacı' (1972: 899a) anlamını vermiştir. Aynı anlam Maitrisimit Nom Bitig'te de görülür (Erdal, 1991: 113). Dolayısıyla yaġıçısı (< yaġı+çı+sı) burada 'mücadelecisi' gibi bir anlamda olmalıdır.

54. satırdaki tügünlüg at 'düğümlü/bağlı at' ibaresinde pek çok kimsenin benimsediği okuma ve anlamlandırma kabul edilmiştir (s. 390). Bu ibare hakkında farklı bir okuma ve anlamlandırma için bk. Uçar, 2021b: 49-55.

56. ve 57. satırlardaki ney yerdeki qaganlig̉ bodunqa bintegi bar erser ne buyı bar erteçi ermiş cümlesi "[Ancak] herhangi bir kağanlı (özgür) halkta benim gibisi [benim gibi deneyimli ve akıllı bir danışman ve komutan] var olursa/var oldukça [o halkın] ne sıkıntısı olacakmış?" ile aktarılmıştır (s. 392-393). Yazıtın bu kısmı epey yıpranmıştır. Yazar, burada <bIntgI> şeklinde yazılan kelimeyi farklı yöntemler kullanarak doğru bir şekilde tespit etmeyi başarmış, önceki okumaları düzeltmiş ve kelimeyi bintegi 'benim gibisi' şeklinde okumuştur (s. 297-298). Yazıtlardaki bintegi'nin nasıl tahlil edileceği sorusu ise hâlâ cevap beklemektedir. Bintegi'yi bin teg+i şeklinde tahlil edebiliriz. İkinci unsur olan teg 'gibi' edatının sonundaki ekin teklik III. şahıs iyelik eki olabileceğini ilk kez Thomsen fark etmiş, ama o cümledeki kelimelerin yapısı ve anlamı hakkında kesin bir şey söylenemeyeceğini itiraf etmek zorunda kalmıştır (1916: 59-60). Erdal, yazıtlarda bir kere geçen bintegi örneği ile beraber antag், montag், sizinteg (< sizni teg), vd. örnekleri de zikrederek teg 'gibi' edatının hâl eki sürecine girmeye başlamasından söz etmekte ve sondaki iyelik ekine bağlamın ihtiyacı olduğunu düşünmektedir (2004: 126-127, 193-194, 336). Erdal'ın zikrettiği teg edatının zamir kökleri ile birleştiği örnekler içinde bintegi onlardan ayrılmaktadır, zira teg edatı burada teklik III. şahıs iyelik ekini almıştır. Eski Türkçede teg edatının teklik III. şahıs iyelik eki aldığı başka bir örneğe yanılmıyorsam rastlanmıyor. Tekin, teg edatının iyelik ekli kullanımı için yazıtlardan antaġııın üçün 'for your being so' (Bilge Qaġan, Kuzey 9) ile Türkiye Türkçesinden onun gibi-si örneklerini delil olarak sunmuştur (1963: 198). Tekin'in verdiği yazıtlardaki örneğin bintegi ile kıyaslanamayacağı açıktır, ama Türkiye Türkçesinden getirdiği onun gibisi tanığ1 dikkate değerdir. Neticede, teg edatının iyelik eki aldığını farz ettiğimizde, teg edatının ya sözlükbirimselleştiğini ya da iyelik ekinin kalıplaştığını kabul etmek gerekiyor. İkincisinin olabileceğine daha çok ihtimal veriyorum. Krş. Azerbaycan Türkçesi teki 'gibi' (Orucov et al., 2006/IV: 297b). Diğer taraftan, şart cümlesiyle teşkil edilen birleşik cümlede yardımcı ve asıl cümlenin fâillerinin de 


\section{ग(৫)}

belirlenmesi gerekmektedir, zira cümlenin anlamı fâillerine göre epey fark etmektedir. Yardımcı cümledeki $\{+\mathrm{kA}\}$ bar er-yapısını '+A sahip olmak' anlamında kabul ettiğim için, yardımcı cümlenin fâilinin eksiltili kullanıma sahip bintegi olabileceğini tahmin ediyor ve birleşik cümleyi şu şekilde anlamlandırmak istiyorum: "Benim gibi [biri] herhangi bir yerdeki qagan sahibi halka sahipse, benim gibi birinin nasıl bir sıkıntısı olacakmış?”. Bu yorumda, cümle sahibi Tuñuquq'un kendini değil, halkını ön plana koyması sözkonusu olmaktadır. Chen'in yukarıda bahsettiğim yorumunu (2021: 146), yani Tuñuquq'un eski görevine dönmek için kendini Bilge Qaġan'a affettirmek amacıyla yazıtları diktirdiğini dikkate alırsak, bu yorumun bağlama daha uygun olduğu da anlaşılacaktır.

5. Bölüm'de metnin sözlüğü ve dizini (s. 415-450) ve 6. Bölüm'de de metnin özel adlar dizini (s. 453-468) yer almaktadır. Eser, 7. Bölüm'deki kaynakça (s. 471517) ile sona ermektedir.

Alyılmaz'ın Bilge Tonyukuk Yazıtları isimli eseri epigrafik belgeleme açısından şimdiye değin yayımlanan neşirler içerisinde müstesna bir yeri hak etmiştir. Tuñuquq yazıtlarına ait iki taşın yakın plandan çekilen resimlerinin bundan sonra yapılacak çalışmalarda temel başvuru kaynağı olarak kullanılacağı kesindir. Yoğun bir mesainin ardından böyle bir eseri vücuda getirip Türkolojiye armağan eden Alyılmaz’ı tebrik ederim.

\section{Kaynakça}

Alyılmaz, C. (2001). Bilge Tonyukuk Yazıtları Üzerine Birkaç Düzeltme. Türk Dili Araştırmaları Ylllı̆ı Belleten 2000, 11-18.

Awğali, E. (2011). Orhon Yazıtlarındaki Bazı Sözlerin Anlambilimsel Karşılıkları Hakkında. In Ölmez, M. et al. (Eds.), Ötüken'den İstanbul'a Türkçenin 1290. Yılı (720-2010) Sempozyumu Bildirileri [3-5 Aralı 2010, İstanbul] (pp. 275-279). İstanbul: İstanbul Büyükşehir Belediyesi Yayınları.

Aydın, E. (2006). Tonyukuk Yazıtı'nda Geçen Ek Tag Üzerine. Belleten, 257, 83-94.

Barthold, W. (1979). Tacik. İslam Ansiklopedisi, XI: Suğd-Tarika. Milli Eğitim Basımevi. İstanbul: 616b-617a.

Bussmann, H. (1996). Routledge Dictionary of Language and Linguistics. Translated and edited by Trauth, G. \& Kazzazi, K. London and New York: Roudledge. 
Chen, Hao (2021). A History of the Second Türk Empire (ca. 682-745 AD). Leiden-Baston: Brill.

Clark, L. (2017). Uygur Manichaean Texts, Texts-Translations-Commentary III: Ecclesiastical Texts. Turnhout (Belgium): Brepols Publishers.

Clauson, Sir G. (1972). An Etymological Dictionary of Pre-Thirteenth Century Turkish. Oxford: Oxford University Press.

Czeglédy, K. (1962). Čoyay-Quzï, Qara-Qum, Kök-Öng. Acta Orientalia Academiae Scientiarum Hungaricae, 15(1), 55-69.

Dankoff, R. \& Kelly, J. (1984). Mahmut el-Kāşyarī: Compendium of the Turkic Dialects (Div̄ān Luүāt at-Türk) II. Harvard: Harvard University Press.

Doerfer, G. (1994). Zu inschrifttürkisch ē/e. Ural-altaische Jahrbücher Neue Folge, 13, 108-132.

Erdal, M. \& Chen, Hao (2017). The Khocho Toñukuk Tradition in Runiform, Uygur and Chinese Sources. Central Asiatic Journal, 60(1), 109-117.

Erdal, M. (1991). Old Turkic Word Formation: A Functional Approach to the Lexicon I-II. Wiesbaden: Harrassowitz Verlag.

Erdal, M. (2004). A Grammar of Old Turkic. Leiden-Boston: Brill.

Fragner, B. G. (2000). Tādjīk. The Encyclopedia of Islam. New Edition, X: T-U. Brill. Leiden: 62a-64b.

Gabain, A. von (1974). Alttürkische Grammatik. 3. Auflage. Wiesbaden: Otto Harrassowitz.

Gemalmaz, E. (2001). Yazıya Geçirme (Transcription) ve Yazıçevirimi (Transliteration). Atatürk Üniversitesi Türkiyat Araştırmaları Enstitüsü Dergisi, 17, 25-37.

Geng, Shimin (2005). 古代突厥文碑銘研究 [Studies of the Old Turkic Inscriptions]. Beijing: Zhongyang Minzu Daxue Chubanshe.

Giraud, R. (1961). L'inscription de Baïn Tsokto (Édition critique). Paris: Librairie d'Amerique et d'Orient.

Kaya, C. (2021a). Bir Başka Açıdan Tonyukuk. In Ildırı, N. \& Kotan, H. (Eds.), Uluslararası Yunus Emre ve Dünden Bugüne Türkçe Sempozyumu Bildirileri (pp. 262-267). Erzurum: Atatürk Üniversitesi Yayınevi.

Kaya, C. (2021b). Uygurca Altun Yaruk, Giriş, Metin ve Dizin. Gözden Geçirilmiş Bask1. Ankara: Türk Dil Kurumu Yayınları. 


\section{0}

Lane, E. W. (1865). An Arabic-English Lexicon II. Edinburgh: Williams and Norgate.

Nauta, A. H. (1969). A Grammar of Orkhon Turkic, by Talât Tekin, Indiana University Publiations, Uralic and Altaic Series, Volume 69, 419 S. Mouton \& co. The Hague 1968. Central Asiatic Journal, 13(4), 308-311. (Rezension)

Orucov, E. et al. (2006). Azerbaycan Dilinin İzahlı Lüğeti I-IV. Bakı: Şerq-Qerb.

Radloff, W. (1899). Die alttürkischen Inschriften der Mongolei, Zweite Folge: die Inschrift des Tonjukuk. St. Petersburg: Buchdruckerei der kaiserlichen Akademie der Wissenschaften.

Róna-Tas, A. (1987). On the Development and Origin of the East Turkic 'Runic' Script. Acta Orientalia Academiae Scientiarum Hungaricae, 4(1), 7-14.

Rybatzki, V. (1997). Die Toñuquq-Inschrift. Szeged: University of Szeged.

Rykin, P. \& Telitsin, N. (2020). An Interpretation of Two Personal Names in the Ninth Line of the Tonyukuk Inscription (Toñ S2). Journal of the American Oriental Society, 140(2), 287-299.

Stachowski, M. (1998). Zwei alttürkische Konsonantenwechsel ( $\check{s} \sim$ s, š $\sim 1$ ), die Runik und die Altaistik. In Laut J. P. \& Ölmez, M. (Eds.), Bahşı Ögdisi, Klaus Röhrborn Armă̆anı (pp. 391-399). Freiburg-İstanbul: Simurg Yayınları.

Tekin, T. (1963). On Kök Turkic “Büntäg1”. Central Asiatic Journal, 8(3), 196-198.

Tekin, T. (1980). Üçüncü Kişi İyelik Eki Üzerine. Genel Dilbilim Dergisi, 2(7-8), 10-17.

Tekin, T. (1994). Tunyukuk Yazıtı. Ankara: Simurg Yayınları.

Tekin, T. (2014). Orhon Yazıtları. 5. Baskı. Ankara: Türk Dil Kurumu Yayınları.

Tezcan, S. (2010). Yazıtlarda Yeni Okuyuş ve Anlamlandırma Önerileri. In Alyılmaz, C. et al. (Eds.), I. Uluslararası Uzak Asya'dan Ön Asya'ya Eski Türkçe Bilgi Şöleni Bildirileri (pp. 273-280). Afyonkarahisar: Afyon Kocatepe Üniversitesi Yayınları.

Thomsen, V. (1916). Turcica; études concernant l'interprétation des inscriptions turques de la Mongolie et de la Sibérie. Helsingfors: Société finno-ugrienn.

Uçar, E. (2017a). Notizen zur Etymologie des alttürkischen özäl- ,sich quälen‘. Central Asiatic Journal, 60(1), 1-11.

Uçar, E. (2017b). Tuñukuk Yazıtındaki nçAYIDms (T I K $10=34$ ) Yazıçevrimi Üzerine Bir Not. Türk Kültürü, 2017/2, 31-38.

Uçar, E. (2021a). A New Interpretation of ...] sün(ü)g(ü)n (a)čd(1)m(1)z (I North 4 = 28) in the Tuńuquq Inscription. Central Asiatic Journal, 63(1), 1-9. 


\section{J(ఠ)}

Uçar, E. (2021b). <tügzlgTG> tüg(ü)zl(ü)g (a)t(1)Y - eine neue Lesart zu <tẅgnlgTG> tög(ü)nl(ü)g (a)t(1)y in den Tuñuquq-Inschriften (II, Ostseite 4 [= Kolumne 54]). Central Asiatic Journal, 64(1-2), 49-55.

Uçar, E. (2021c). Tuñuquq Yazıtlarının 8. Satırındaki (I/Güney 1) İki Müphem Cümle veya Problemli Bir Runik İşaret Üzerine. Türkbilig, 42, 19-26.

Uçar, E. (2022). Tuñuquq Yazıtlarında İnce Sıradaki Ok Enklitiğinin Yazımı ve Bazı Satırların (11 = I/G 4, $16=\mathrm{I} / \mathrm{G}$ 9, $21=\mathrm{I} / \mathrm{D} 4$ ve $30=\mathrm{I} / \mathrm{K}$ 6) Yeniden Yorumlanması. Journal of old Turkic Studies, 6(1), 135-147.

Wilkens, J. (2021). Handwörterbuch des Altuigurischen, Altuigurisch-Deutsch-Türkisch. Göttingen: Universitätsverlag Göttingen.

Yıldız, H. (2013). Sıska ve Semiz Boğa Uzakta Ne Yapıyordu? Türk Dilleri Araştırmaları, 23(2), 113-134. 